\title{
Reply to "Ichthyosaur embryos outside the mother body: not due to carcass explosion but to carcass implosion" by van Loon (2013)
}

\author{
Achim G. Reisdorf • Gail S. Anderson • Lynne S. Bell • Christian Klug • \\ Annette Schmid-Röhl • Hans-Joachim Röhl • Michael Jung • Michael Wuttke • \\ Michael W. Maisch • Mark Benecke • Daniel Wyler • Roman Bux • Peter Fornaro • \\ Andreas Wetzel
}

Received: 25 February 2014 / Accepted: 3 April 2014 /Published online: 29 May 2014

(C) Senckenberg Gesellschaft für Naturforschung and Springer-Verlag Berlin Heidelberg 2014

In his recent discussion on the taphonomy of ichthyosaurs, van Loon (2013) supported - at least partially - the view of Reisdorf et al. (2012) and emphasized that explosion of vertebrate carcasses on the sea floor should not be considered as a taphonomically reasonable scenario. Carcass explosion is thus not a process that can be used to explain both the disarticulation of certain ichthyosaur skeletons and the displacement of their bones in the geological record. Van Loon (2013),

A. G. Reisdorf $(\bowtie) \cdot$ A. Wetzel

Geologisch-Paläontologisches Institut, Universität Basel,

Bernoullistrasse 32, 4056 Basel, Switzerland

e-mail: Achim.Reisdorf@unibas.ch

\section{A. G. Reisdorf \\ Naturhistorisches Museum der Burgergemeinde, Bernastrasse 15, 3005 Bern, Switzerland}

\section{G. S. Anderson • L. S. Bell}

Centre for Forensic Research, School of Criminology, Simon Fraser University, Burnaby, British Columbia, Canada

\section{Jung}

Ubootgeschwader, Hydroakustisches Analysezentrum der Marine, Am Ort 6, 24340 Eckernförde, Germany

\section{R. Bux}

Institut für Rechtsmedizin und Verkehrsmedizin,

Universitätsklinikum Heidelberg, Voßstraße 2, 69115 Heidelberg,

Germany

\section{Wyler}

Institut für Pathologie und Rechtsmedizin des Kantonspitals

Graubünden, Loëstrasse 170, 7000 Chur, Switzerland

\section{Benecke}

International Forensic Research \& Consulting, Postfach 250411, 50520 Cologne, Germany however, did suggest that, as an alternative hypothesis, implosion could have led to the displacement of bones on the sea floor.

Van Loon (2013) focussed his explanation of the implosion hypothesis on the example of a maternal ichthyosaur having embryonic ichthyosaurs around and within its body cavity (Staatliches Museum für Naturkunde Stuttgart, specimen number SMNS 50 007). Reisdorf et al. (2012) outlined that
C. Klug

Paläontologisches Institut und Museum, Universität Zürich, Karl Schmid-Strasse 4, 8006 Zurich, Switzerland

M. W. Maisch

Institut für Geowissenschaften, Eberhard Karls-Universität

Tübingen, Hölderlinstraße 12, 72074 Tübingen, Germany

A. Schmid-Röhl

Holcim (Süddeutschland) GmbH, Fossil Museum, Dormettinger Straße 23, 72359 Dotternhausen, Germany

H.-J. Röhl

Hornschuchstraße 5, 72074 Tübingen, Germany

M. Wuttke

Generaldirektion Kulturelles Erbe RLP, Große Langgasse 29, 55116 Mainz, Germany

P. Fornaro

Imaging and Media Lab, Universität Basel, Bernoullistrasse 32, 4056 Basel, Switzerland 
this maternal specimen is just one example of many similar cases. In fact, Reisdorf et al. (2012) challenged the hypothesis of carcass explosion based on numerous ichthyosaur finds, which are preserved in the Lower Jurassic (Toarcian) Posidonienschiefer Formation in SW Germany; however, most of these are specimens without embryos. The generalised taphonomic model suggested by Reisdorf et al. (2012) can also be applied to other vertebrates if their anatomical peculiarities are taken into account (Reisdorf and Wuttke 2013). Therefore, in the following assessment and discussion, the focus is not on this specific specimen SMNS 50007 but on the question of whether vertebrate carcasses can implode after having settled to the sea floor as well as on the related physical and physiological aspects.

The hypothesis of van Loon (2013) is based on three main assumptions: (1) bodies of ichthyosaur should have had a lower density than seawater in vivo (van Loon 2013: p. 105); (2) putrefaction gases could have filled some (connected) cavities within the carcass even at hydrostatic pressures of 5-15 bar (= water depth 50-150 m; van Loon 2013: p. 107); (3) on the sea floor at a water depth of 50$150 \mathrm{~m}$, an underpressure has developed/maintained within the ichthyosaur carcass (van Loon 2013: 107); van Loon invoked a submarine as analogue (van Loon 2013: 107). These three assumptions are discussed in detail in the following text.

(1) Van Loon (2013) provides no explanation as to how a vertebrate carcass having a lower density than the ambient fluid may have settled to the sea floor, in particular as putrefaction gases may accumulate in some body cavities during the time when the carcass floated at the sea surface. The latter process lowers the mean density of the carcass. A low body density would have resulted in a prolonged floating interval of the carcass at the sea surface. During that time, the carcass is subjected to biogenic and physical destruction, with all its taphonomic consequences (i.e. loss of soft tissue and possibly even bones due to decomposition processes, scavenging and wave action). In contrast, a large number of the Early Toarcian ichthyosaurs of SW Germany are preserved as more or less complete skeletons (e.g. Hofmann 1958; Heller 1966; Keller 1992; Martill 1993) and thus, they must have sunk in toto to the sea floor immediately after death (Reisdorf et al. 2012). Settling of an ichthyosaur carcass to the sea floor would have required a body density higher than that of seawater as explained by Reisdorf et al. (2012: pp 72, 75 and references therein).

(2) Putrefaction gases forming in subaquatic settings mainly consist of $\mathrm{CO}_{2}, \mathrm{H}_{2}$ and $\mathrm{N}_{2}$, (Mallach and Schmidt 1980; Kelly 1990; Bernaldo de Quirós et al. 2013), which have a considerable solubility in water under hydrostatic pressures of $>5$ bar (Weiss 1970, 1974; Wiesenburg and Guinasso 1979; Reisdorf et al. 2012). Accordingly, these gases are soluble within the carcass bodily fluids, and soft tissues that become increasingly fluidized during autolytical processes and putrefaction (e.g. Teather 1994). Therefore, the volume of undissolved putrefaction gases is low in carcasses located at water depths of 50-150 m (compare Figs. 1 and 2; see explanation and references in Reisdorf et al. 2012: p. 72; Reisdorf and Wuttke 2012: p. 155). During residence on the sea floor, fluidization of soft tissues leads to an increasingly plastic consistency of the carcass which, in combination with the necessarily small volumes of putrefaction gas within the carcass, if ever present, rules out the implosion scenario invoked by van Loon (2013). Nevertheless, a simple gravitational collapse of the body due to soft-tissue fluidization and the loss of connectivity of the skeletal elements is highly likely (e.g. Hofmann 1958; Kauffman 1981; Keller 1992; Martill 1993), but this process does not represent an 'implosion'. It is physiologically and physically impossible to generate or to maintain an underpressured cavity within a vertebrate carcass on the sea floor at water pressures ranging from 5 to 15 bar. Unfortunately, van Loon (2013) provides neither a physical explanation nor experimental evidence as to how such an underpressure might have developed or have been maintained within a vertebrate carcass on the sea floor. His comparison of a submerged carcass with a submarine is not valid because a submarine has a rigid outer shell (e.g. Polmar 2004; in terms of palaeontology this corresponds to a rigid exoskeleton, which is the case for certain cephalopods; e.g. Hewitt and Westermann 1987; Kanie and Hattori 1983). In contrast, ichthyosaurs have an endoskeleton covered by flexible skin and multiple openings that allow for the exchange of gases and fluids with the ambient seawater and also for a certain degree of deformation of the rib cage (Taylor 1987, 2000; Hänggi and Reisdorf 2007: p. 13). Therefore,

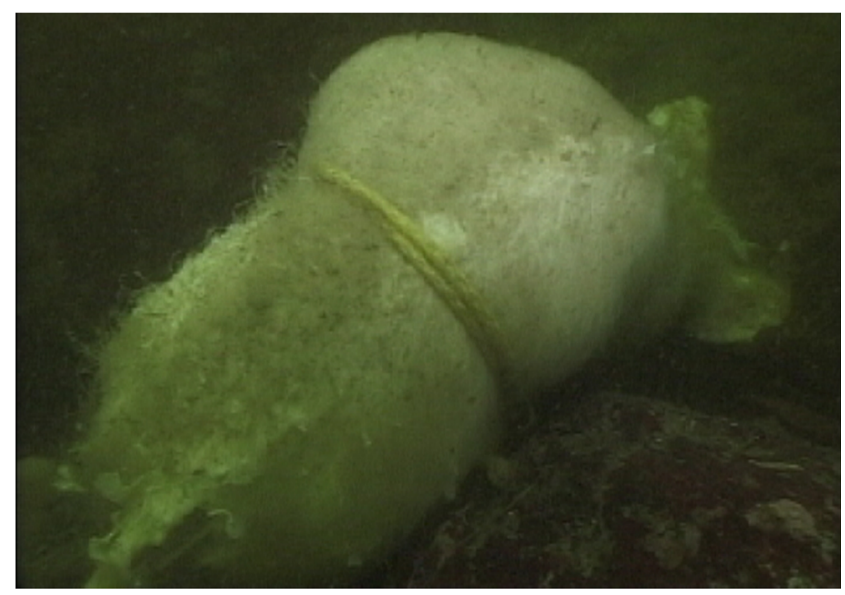

Fig. 1 Bloated pig carcass in shallow waters (water depth 7-15 m) in Howe Sound, British Columbia. Bloat lasted 3-10 days (G.S. Anderson; see also Anderson 2010; Kelly 1990). (Photograph by J. Haywood) 


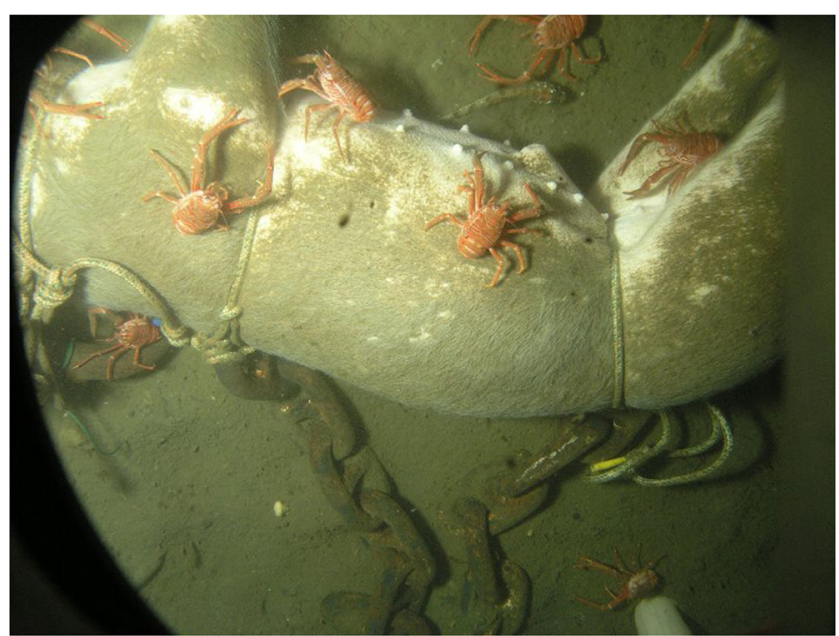

Fig. 2 Pig carcass at a water depth of 99 m, 5 days after placement in Saanich Inlet, British Columbia (water temperature $9.2^{\circ} \mathrm{C}$ ). No evidence of bloat (for detailed information as well as faunal colonization, see Anderson 2010; Anderson and Bell 2010). [Photograph by VENUS Project (Victoria Experimental Network Under the Sea), G.S. Anderson and L.S. Bell]

van Loon's (2013) implosion hypothesis has no physical basis. At the most, a carcass may gravitationally collapse on the sea floor.

(3) Referring to the example of the above-mentioned gravid female, van Loon (2013) proposes that its implosion led to the dissemination of embryo bones. The power of an implosion, of course, depends on the total connected volume being underpressured, the underpressure relative to the ambient setting and the speed of pressure equilibration. Is it possible that a large gas-filled, but sufficiently underpressured cavity to implode could develop at the sea floor? At the hydrostatic pressure present at a considerable water depth, putrefaction gases become dissolved in the surrounding liquids and tissues, forming numerous, small-sized bubbles (= 'gas crepitation'; e.g. Dumser and Türkay 2008), or they are maintained in small pockets of the decaying body (e.g. Anderson 2010). They do not accumulate to form a large balloonlike volume (compare Figs. 1 and 2; e.g. Anderson 2010). Therefore, putrefaction gases are unlikely to be available for an implosion. Furthermore, there is currently no experimental observation or theory that explains how to develop an underpressure in a newly formed or persisting gas- or liquid-filled cavity within a vertebrate carcass at the sea floor. Van Loon (2013) did neither provide an explanation that is physically and physiologically sound nor did he obtain experimental evidence or provide an explanation about how, where and why the 'implosion centre' developed. To our knowledge, it is highly unlikely that a reasonably large, underpressured gas-filled volume develops in a carcass on the sea floor without a sufficiently rigid frame to physically explain an implosion. In contrast, the most common and plausible scenario for a carcass on the sea floor would appear to be a gradual gravitational collapse of the skeleton due to decaying soft-tissues and the loss of connectivity of the skeletal elements.

From the physical point of view, there has to be a spatial relation between the location of the underpressured cavity, the area of skin damage through which pressure equilibration took place and the dissemination of bones. However, van Loon (2013) did not provide any evidence or other arguments in support of the implosion hypothesis; for instance, he did not state where such underpressured volumes might have been located within the carcass and how the implosion of the carcass would have been expressed taphonomically. The anatomy of (extant) viviparous reptiles does not show any peculiarity that would lead to the implosion of a carcass under natural conditions at a considerable water depth (e.g. Gans and Parsons 1977; cf. Böttcher 1990; Blackburn et al. 2003; Maxwell and Caldwell 2003; Kear and Zammit 2014; Motani et al. 2014). In fact, to date, there has been no published report about the implosion of a vertebrate carcass on the sea floor. In contrast, the physiology of extant lung-breathing vertebrates clearly illustrates that the body with its endoskeleton and lungs passively responds to an increase in hydrostatic pressure (e.g. Hui 1975; Ridgway et al. 1969; Kooyman 1989). For example, the body is compressed within the anatomically possible range if external pressure increases during (deep) diving (see conclusions and references in Reisdorf et al. 2012: p. 76). The same is true for extant dolphins, which have been suggested to represent a modern analogue to ichthyosaurs with respect to adaptation to the marine habitat (e.g. Ridgway et al. 1969; Hui 1975; McGhee 2011; Zammit et al. 2014). Ichthyosaur thoraxes were adapted to dive to reasonably great depths similar to those of extant Cetaceans (e.g. Taylor 1987, 2000). In addition, even the fairly rigid thorax of terrestrial mammals (including humans) has some flexibility and becomes compressed at water depths of $>10 \mathrm{~m}$ (e.g. Kelly 1990). In other words, if dead lung-breathing vertebrates sink to the sea floor, their density increases due to the compression of the gas-filled spaces in the body as well as compression and dissolution of the gas inside the respiratory tract (see Reisdorf et al. 2012, and references therein). In such cases, no underpressure can develop. Modern observations support this view: Smith and Baco (2003) demonstrated that cetacean carcasses bloated by putrefaction gases settled to the sea floor as deep as 1,900 m (substantial amounts of ballast, up to $2.7 \mathrm{t}$, were used to sink them), but they did not implode, even if they were attacked by scavengers at this depth. These examples illustrate again that submarines do not 
represent suitable analogues for ichthyosaurs, neither for living or for dead ones. To conclude, van Loon's (2013) scenario of a carcass implosion has neither a physical nor a physiological base. Therefore, we disagree with van Loon's hypothesis of carcass implosion.

Additionally, carcass implosion does not provide an explanation for the dissemination of (ichthyosaur) bones on the sea floor [in, for example, a stagnant basin sensu Seilacher (1982), like that of the Early Toarcian epicontinental sea]. In contrast, the fluidization of the soft tissues during decomposition and the effects of bottom currents on the carcass may lead to the translocation of anatomic units and thus disarticulation as well as dislocation of bones. Fluidization may have allowed an effluence of a viscous mass carrying disarticulated bones when the skin becomes locally damaged (e.g. by scavengers) or partly degraded (Wuttke and Reisdorf, in preparation).

In fact, there are many indicators of bottom-current activity in the epicontinental sea covering Central Europe during the Toarcian, although this was doubted by van Loon (2013). The Mesozoic Central European Epicontinental Sea (Wetzel et al. 2013) was partly surrounded by landmasses and shallow seaways to the open oceans, to the Arctic Sea to the north and to the Tethys to the SW, while in the SE between the Alemannic Island a shallow shoal existed (e.g. Ziegler 1990; Cope et al. 1992; Röhl and Schmid-Röhl 2005; Suan et al. 2013). While located roughly around $35^{\circ} \mathrm{N}$ in a warm climate, terrigenous clastics form the major proportion of the sediment of the Posidonienschiefer Formation, implying a considerable influx of river water, mainly from Scandinavia and the Bohemian Massif (e.g. Prauss et al. 1991; Cope et al. 1992; Bour et al. 2007; cf. Harazim et al. 2013). The high amount of organic matter and the fine-lamination and dark colour of the sediment are seen as evidence for temporary anaerobic conditions at the sea floor and a stratified water body (e.g. Röhl et al. 2001; Bour et al. 2007).

Since this epicontinental basin was connected to the world ocean at different sides by fairly wide gateways, storms and similar events probably introduced dense ocean water into the Posidonienschiefer basin (cf. Bour et al. 2007; Harazim et al. 2013). Depending on the sea floor topography and the power of the (storm-) events current-reworked layers extend more or less far into the basin. The influx of dense ocean water was often followed by short-term oxygenation at the sea floor (e.g. Bour et al. 2007). Less intense events might have resulted in sediment reworking only. It is also possible that a continuous flow of dense oceanic water existed for short periods of time that share some similarities with contour current deposits outlined by van Loon (2013: p. 106); we fully agree with this statement. During times of enhanced precipitation it is most likely that an estuarine circulation was established within the basin, whereas during periods of prevailing evaporation, dense saline downwelling water would

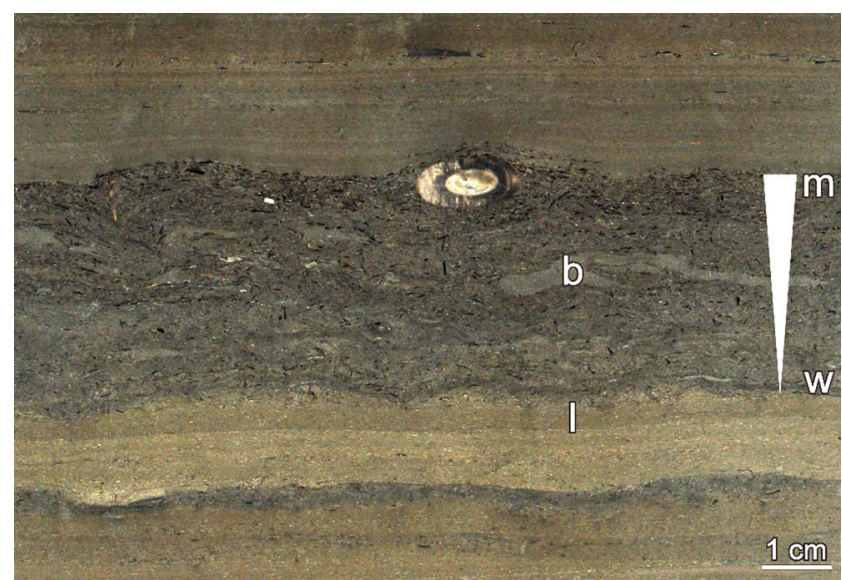

Fig. 3 Current reworking of sediment by the bottom current that increased in flow velocity as indicated by the inverse grading. Prior to the main episode $(m)$, weaker reworking $(w)$ occurred; the onset of the latter is marked by the absence of lamination $(l)$. During the main event the sea floor was oxygenated, as indicated by the burrows $(b)$. (Temporary exposure at Pädagogische Hochschule Reutlingen/Germany, lower commune subzone, above the limestone bed 'Inoceramenbank'; Photograph by A. Wetzel)

have initiated an anti-estuarine circulation (e.g. Röhl 1998; Röhl et al. 2001).

It is not the purpose of this commentary to explain how the bottom currents within the Posidonienschiefer basin would have been initiated; rather, our aim is to provide evidence for their existence and effects. Many studies describe the effects of such bottom currents; for example, current-related sedimentary structures and alignment of fossil hard parts have been documented by Bour et al. (2007), Kauffman (1979, 1981), Martill (1993), Röhl (1998), Seilacher (1982, and references therein) and Schieber et al. (2007). For ichthyosaurs, Brenner

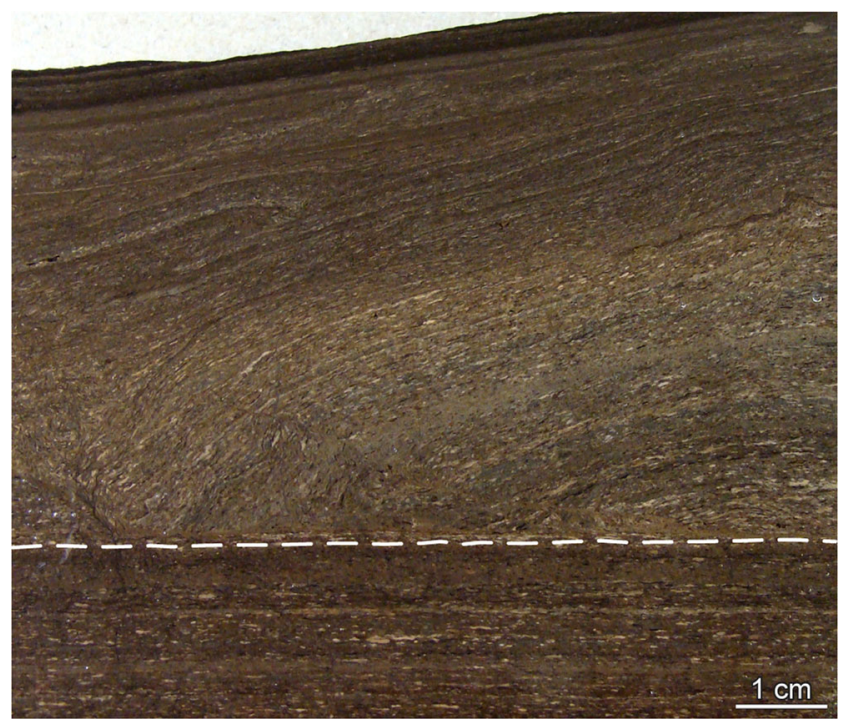

Fig. 4 Mass movement within the Posidonia-Shale; base marked by broken line. Note folding. (Temporary exposure at Pädagogische Hochschule Reutlingen/Germany, lower commune subzone, above the limestone bed 'Inoceramenbank'; Photograph by A. Wetzel) 


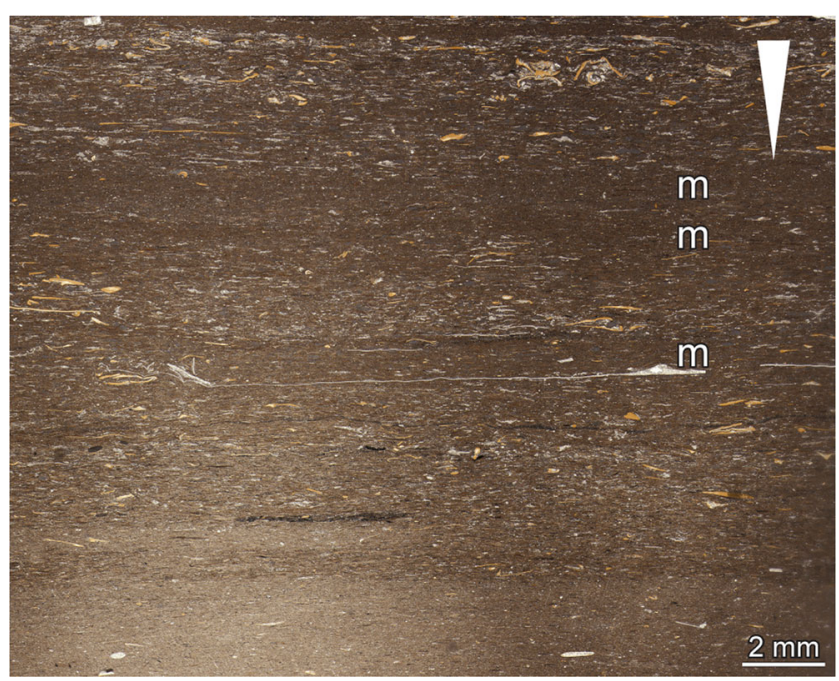

Fig. 5 Thin section of an interval with fluctuating bottom current activity as evidenced by subtle inverse grading and enrichment of fossil debris and layerwise enrichment of mud $(m)$. Inversely graded interval with upward increasing content of coarse material is marked by a white arrowhead. (Temporary exposure at Pädagogische Hochschule Reutlingen/Germany, lower commune subzone, above the limestone bed 'Inoceramenbank'; Photograph by A. Wetzel)

(1976a, b), Brenner and Seilacher (1979), Hofmann (1958) and Osborn (1905) have provided examples supporting the hypothesis of bottom currents that affected the sea floor of the Posidonienschiefer basin.

A variety of primary sedimentary structures and bioturbation structures occur in the Toarcian Posidonienschiefer
Formation of SW Germany. They include centimetres-thick, partly bioturbated layers consisting of reworked sediment (Fig. 3), mass flow deposits (Fig. 4), reworked sediment layers characterised by oriented sediment components (Fig. 5) and thin layers indicating moderate to weak currents (Fig. 6). Such layers are more frequent than has been commonly assumed, although only very few such examples have been published (Figs. 3, 4 and 5) or they are somewhat hidden in the literature (Riegraf et al. 1984; Riegraf 1985; Wetzel and Uchman 1998). Nonetheless, careful observations led Kauffman $(1979,1981)$ to question the stagnant basin model. It is not the purpose of this commentary to continue this debate on Seilacher's (1982) model; rather, we wish to draw the reader's attention to the frequent occurrence of current indicators.

Given the vertical extent of a dead adult ichthyosaur sinking to the sea floor, it is highly likely that due to the low average net sedimentation rate $[4 \mathrm{~mm} / \mathrm{kyr}$ (compacted), equivalent to $40 \mathrm{~mm} / \mathrm{kyr}$ in a decompacted state at approx. $90 \%$ porosity; see Einsele and Mosebach 1955 as well as Hofmann 1958, for an estimate) the elevated parts of the carcass are exposed to currents for a considerably long time span. This rate is as low as today in the deep-sea $(20-60 \mathrm{~mm} / \mathrm{kyr}$; e.g. Scholle et al. 1983). As long as a carcass is not completely embedded within the sediment it can be affected by currents. Theoretically, it would take $20 \mathrm{kyr}$ to fully cover a ichthyosaur carcass of a diameter of $80 \mathrm{~cm}$ with sediment at the given sedimentation rates and under conditions of the absence of carcass collapse (see also Martill 1993), but it is an extremely
Fig. 6 Thin sections of layers indicating bottom current activity. a Layers exhibit a sharp base (white arrowhead) that is enriched in fossil debris due to condensation and winnowing ('Schlacken'); note the considerable proportion of fish scales and other phosphatic debris (brownish in colour). b Several thin layers $(s, w)$ with condensed debris and bivalve shells indicate benthic colonization events according to Röhl et al. (2001), some of them with a sharp base (white arrowhead) laminated mud $(\mathrm{lm})$ in between meets the criteria given by Schieber et al. (2007) for deposition by currents. (Temporary exposure at Pädagogische Hochschule Reutlingen/Germany, lower commune subzone, above the limestone bed 'Inoceramenbank'; Photographs by A. Wetzel)
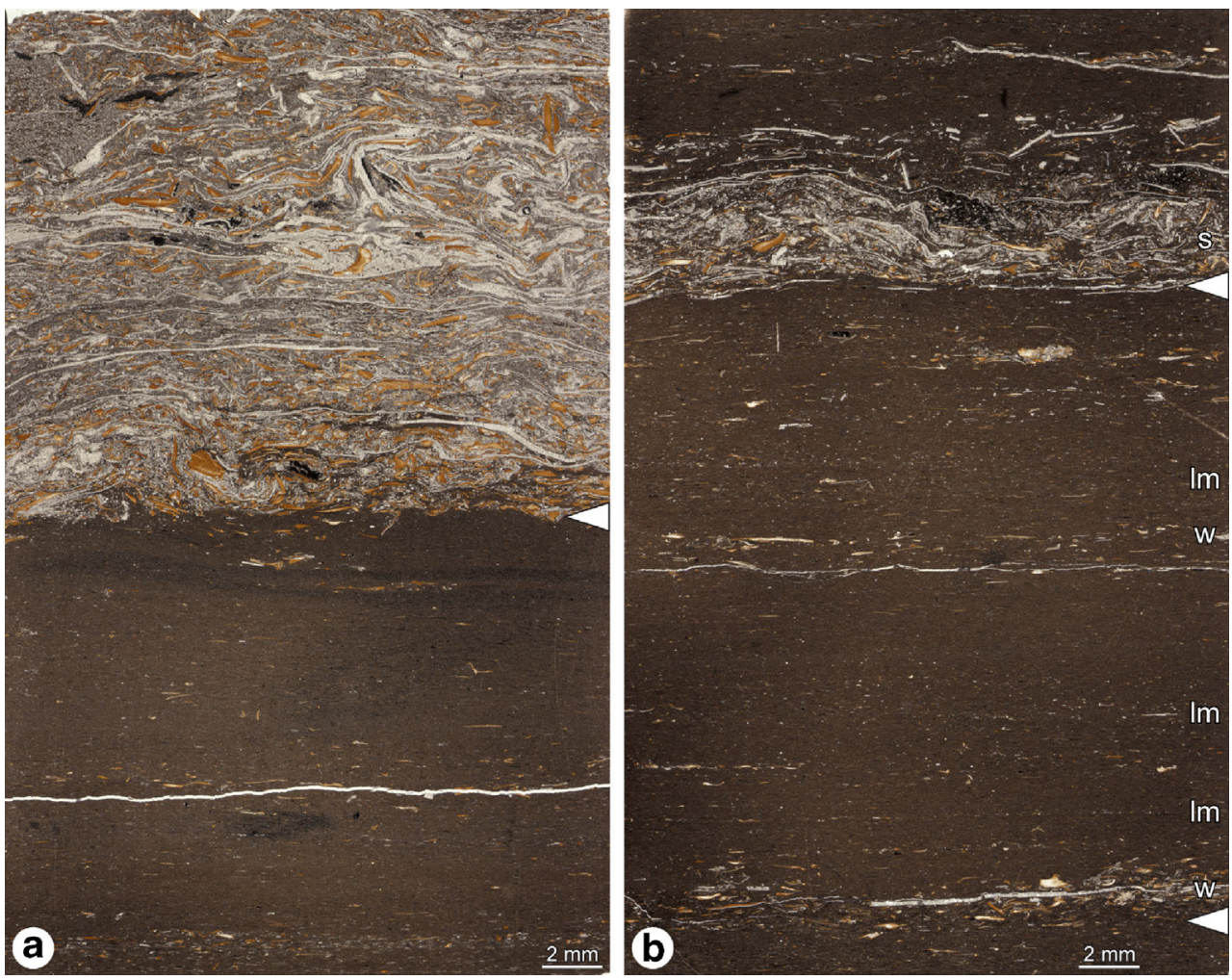
dubious assumption that a carcass prevails over thousands of years without being effected by decay. As van Loon (2013) outlined, degradation of a carcass, however, might have affected the soft parts within a relatively short time. Even then, the articulated bones still form elevations on the sea floor for some time and could have been affected more easily by currents than the adjacent sea floor according to Bernoulli's principle (e.g. Vogel 1994). Furthermore, ichthyosaur bones consist mostly of spongiosa, and hence they have a relatively low density (and thus a small hydraulically equivalent diameter) that facilitates their displacement by currents (see explanation by Reisdorf et al. 2012 and references therein).

Van Loon doubts that some ichthyosaur carcasses sunk-at least partly —into the sea floor sediment, which most likely had a soupy consistency (Hofmann 1958; Martill 1993; Schmid-Röhl and Röhl 2003) that would have allowed their articulated preservation (some of them even with a preserved body outline = so-called 'soft tissue preservation'; e.g. Heller 1966; Hauff and Hauff 1981; Martill 1993; Lindgren et al. 2014). Unfortunately, van Loon (2013) did not provide an alternative embedding mechanism for such ichthyosaurs. Van Loon (2013) argued that, for example, empty extant shells with a considerably higher density do not sink into soupy mud. However, some ichthyosaurs carcasses did sink into the sediment of the Posidonienschiefer Formation, as evidenced by their mode of preservation; normally the lower surface of the specimens is prepared and exposed in museums because the upper side is preserved at a considerable lower quality, as described in detail by Heller (1966), Hofmann (1958) and Martill (1993). In this context it has to be taken into account that the density of ichthyosaurs became higher during the sinking process to the sea bottom due to compression of the thorax and, therefore, the carcasses achieved a certain acceleration as they sank through the water column to the sea bottom (Reisdorf 2007; Reisdorf et al. 2012; in contrast to the benthonic fauna, e.g. shells). As shown by Fröbisch et al. (2006), Hänggi and Reisdorf (2007), Hofmann (1958), Martill (1993), Reisdorf (2007), Wahl 2009 as well as Wetzel and Reisdorf (2007), this high settling speed is corroborated by many excellent ichthyosaurs specimens all over the world, which landed head-first on the sea floor with the snout penetrating several decimetres into the uncompacted sediment.

Some stratigraphic intervals contain almost only isolated bones of ichthyosaurs, whereas others contain more or less completely preserved, but disarticulated ichthyosaur skeletons in relatively high abundance. The latter horizons correspond to episodes of rising or high sea-level, whereas isolated bones occur more frequently in deposits that formed during falling or low sea-level [based on the sea-level charts of Haq et al. (1988) and Hallam (1988, 2001)]. Reisdorf et al. (2012) explained this coincidence by their taphonomic hypothesis. Van Loon criticised this explanation without comprehensive reasoning or alternative hypotheses. In the absence of alternative hypotheses and a convincing falsification, we still favour our hypothesis of the relationship between sea-level fluctuations and preservation of ichthyosaurs.

In any case, the discussion of van Loon is most welcome because each critical examination of existing sedimentological and palaeontological models and hypotheses represents a further step towards our better understanding of the processes involved.

\section{References}

Anderson GS (2010) Decomposition and invertebrate colonization of cadavers in coastal marine environments. In: Amendt J, Campobasso CP, Goff ML, Grassberger M (eds) Current concepts in forensic entomology. Springer, Dordrecht, Heidelberg, London, New York, pp 223-272

Anderson GS, Bell LS (2010) Deep coast marine taphonomy: interim results from an ongoing experimental investigation of decomposition in the Saanich Inlet, British Columbia. Proc Am Acad Forensic Sci 16:381-382

Bernaldo de Quirós Y, Seewald JS, Sylva SP, Greer B, Niemeyer M, Bogomolni AL, Moore MJ (2013) Compositional discrimination of decompression and decomposition gas bubbles in bycaught seals and dolphins. PLoS ONE 8(12):e83994. doi:10.1371/journal.pone. 0083994

Blackburn DG, Weaber KK, Stewart JR, Thompson MB (2003) Do pregnant lizards resorb or abort inviable eggs and embryos? Morphological evidence from an Australian skink, Pseudemoia pagenstecheri. J Morphol 256:219-234

Böttcher R (1990) Neue Erkenntnisse über die Fortpflanzungsbiologie der Ichthyosaurier. Stuttgarter Beitr Naturk B 164:1-51

Bour I, Mattioli E, Pittet B (2007) Nannofacies analysis as a tool to reconstruct paleoenvironmental changes during the early Toarcian anoxic event. Palaeogeogr Palaeoclimatol Palaeoecol 249:58-79

Brenner K (1976a) Ammonitengehäuse als Anzeiger für Paläoströmungen. N Jb Geol Paläont, Abh 151:101-118

Brenner K (1976b) Schwarzschiefer biostratinomische Untersuchungen im Posidonienschiefer (Lias epsilon, Unteres Toarcium) von Holzmaden (Württemberg, Süd-Deutschland). Zbl Geol Paläont 2: 223-226

Brenner K, Seilacher A (1979) New aspects about the origin of the Toarcian Posidonia Shales. N Jb Geol Paläont, Abh 157:11-18

Cope JCW, Ingham JK, Rawson PF (1992) Atlas of palaeogeography and lithofacies. Geol Soc Mem 13:1-152

Dumser TK, Türkay M (2008) Postmortem changes of human bodies on the Bathyal Sea Floor - two cases of aircraft accidents above the open sea. J Forensic Sci 53:1049-1052

Einsele G, Mosebach R (1955) Zur Petrographie, Fossilerhaltung und Entstehung der Gesteine des Posidonienschiefers im Schwäbischen Jura. N Jb Geol Paläont, Abh 101:319-430

Fröbisch NB, Sander M, Rieppel O (2006) A new species of Cymbospondylus (Diapsida, Ichthyosauria) from the Middle Triassic of Nevada and a re-evaluation of the skull osteology of the genus. Zool J Linn Soc 147:515-538

Gans C, Parsons TS (eds) (1977) Biology of the Reptilia. Morphology E. Academic Press, London, New York 
Hallam A (1988) A re-evaluation of the Jurassic eustasy in the light of new data and the revised Exxon curve. SEPM Soc Sed Geol Spec Publ 42:261-273

Hallam A (2001) A review of the broad pattern of Jurassic sea-level changes and their possible causes in the light of current knowledge. Palaeogeogr Palaeoclimatol Palaeoecol 167:23-37

Hänggi H, Reisdorf AG (2007) Der Ichthyosaurier vom Hauensteiner Nebelmeer-Wie eine Kopflandung die Wissenschaft Kopf stehen lässt. Mitt Naturforsch Ges Kanton Solothurn 40:7-22

Haq BU, Hardenbol J, Vail PR (1988) Mesozoic and Cenozoic chronostratigraphy and cycles of sea-level change. SEPM Spec Publ 42:71-108

Harazim D, Van De Schootbrugge B, Sorichter K, Fiebig J, Weug A, Suan G, Oschmann W (2013) Spatial variability of watermass conditions within the European Epicontinental Seaway during the Early Jurassic (Pliensbachian-Toarcian). Sedimentology 60:359390

Hauff B, Hauff RB (1981) Das Holzmadenbuch. Hauff \& Hauff, Holzmaden, Teck

Heller W (1966) Untersuchungen zur sogenannten Hauterhaltung bei Ichthyosauriern aus dem Lias epsilon Holzmadens (Schwaben). N Jb Geol Paläont, Mh 1966:304-317

Hewitt RA, Westermann GEG (1987) Post-mortem behaviour of Early Paleozoic nautiloids and paleobathymetry. Paläontol Z 70:405-424

Hofmann J (1958) Einbettung und Zerfall der Ichthyosaurier im Lias von Holzmaden. Meyniana 6:10-55

Hui CA (1975) Thoracic collapse as affected by the retia thoracica in the dolphin. Respir Physiol 25:63-70

Kanie Y, Hattori M (1983) Shell implosion depth of living Nautilus. Occas Pap 1:30-35

Kauffman EG (1979) Benthic environments in paleoecology of the Posidonienschiefer (Toarcian). N Jb Geol Paläont, Abh 157:18-36

Kauffman EG (1981) Ecolocial reappraisal of the German Posidonienschiefer and the Stagnant Basin Model. In: Gray J, Boucot AJ, Berry WBN (eds) Communities of the past. Hutchinson Ross, Stroudsburg, pp 311-381

Kear BP, Zammit M (2014) In utero foetal remains of the Cretaceous ichthyosaurian Platypterygius: ontogenetic implications for character state efficacy. Geol Mag 151:71-86

Keller T (1992) "Weichteil-Erhaltung" bei großen Vertebraten (Ichthyosauriern) des Posidonienschiefers Holzmadens (Oberer Lias, Mesozoikum Süddeutschlands). Kaupia-Darmstädter Beitr Naturgesch 1:23-62

Kelly D (1990) Postmortem gastrointestinal gas production in submerged Yucatan micro-pigs. Unpublished MA thesis. Colorado State University, Fort Collins

Kooyman GL (1989) Diverse divers. Springer, Berlin, Heidelberg

Lindgren J, Sjövall P, Carney RM, Uvdal P, Gren JA, Dyke G, Schultz BP, Shawkey MD, Barnes KR, Polcyn MJ (2014) Skin pigmentation provides evidence of convergent melanism in extinct marine reptiles. Nature 506(7489):484-488. doi:10.1038/nature12899

Mallach HJ, Schmidt WK (1980) Über ein quantitatives und qualitatives Verfahren zum Nachweis der Luft- oder Gasembolie. Beitr Gerichtl Med 38:409-419

Martill DM (1993) Soupy substrates: a medium for the exceptional preservation of ichthyosaurs of the Posidonia Shale (Lower Jurassic) of Germany. Kaupia-Darmstädter Beitr Naturgesch 2:77-97

Maxwell EE, Caldwell MW (2003) First record of live birth in Cretaceous ichthyosaurs: closing an 80 million year gap. Proc R Soc Lond Ser B 270[Suppl]:S104-S107

McGhee GR (2011) Convergent evolution: limited forms most beautiful. The MIT Press, Cambridge, London

Motani R, D-y J, Tintori A, Rieppel O, G-b C (2014) Terrestrial origin of viviparity in Mesozoic marine reptiles indicated by early Triassic embryonic fossils. PLoS ONE 9:e88640
Osborn HF (1905) Ichthyosaurs. The evolution of fitness in ichthyosaurs (Fossil wonders of the West). Cent Mag 69:414-422

Polmar N (2004) The death of the U.S.S. Thresher: the story behind history's deadliest submarine disaster. Lyons Press, Guilford

Prauss M, Ligouis B, Luterbacher H (1991) Organic matter and palynomorphs in the "Posidonienschiefer" (Toarcian, Lower Jurassic) of southern Germany. In: Thyson RV, Pearson TH (eds) Modern and ancient continental shelf anoxia. Geol Soc Spec Publ 58:335-351

Reisdorf AG (2007) No joke movement: Mehr über den Hauensteiner Ichthyosaurier und rezente marine Lungenatmer. Mitt Naturforsch Ges Kanton Solothurn 40:23-49

Reisdorf AG, Wuttke M (2012) Re-evaluating Moodie's OpisthotonicPosture Hypothesis in fossil vertebrates. Part I: reptiles - the taphonomy of the bipedal dinosaurs Compsognathus longipes and Juravenator starki from the Solnhofen Archipelago (Jurassic, Germany). In: Wuttke M, Reisdorf AG (eds) Taphonomic processes in terrestrial and marine environments. Palaeobio Palaeoenv 92: $119-168$

Reisdorf AG, Wuttke M (2013) Exploding the myth: can carcasses explode? In: 57th Annu Meet Palaeont Assoc (Programme and Abstracts). The Palaeontological Association. Zurich, p 84

Reisdorf AG, Bux R, Wyler D, Benecke M, Klug C, Maisch MW, Fornaro P, Wetzel A (2012) Float, explode or sink: post-mortem fate of lung-breathing marine vertebrates. In: Wuttke M, Reisdorf AG (eds) Taphonomic processes in terrestrial and marine environments. Palaeobio Palaeoenv 92:67-81

Ridgway SH, Scronce BL, Kanwisher J (1969) Respiration and deep diving in the bottlenose porpoise. Science 166:1651-1654

Riegraf W (1985) Mikrofauna, Biostratigraphie und Fazies im Unteren Toarcium Südwestdeutschlands und Vergleiche mit benachbarten Gebieten. Tübinger Mikropal Mitt 3:1-232

Riegraf W, Werner G, Lörcher F (1984) Der Posidonienschiefer. Enke, Stuttgart

Röhl H-J (1998) Hochauflösende palökologische und sedimentologische Untersuchungen im Posidonienschiefer (Lias $\varepsilon$ ) von SWDeutschland. Tübinger Geowissenschaft Arb Reihe A 47:1-170

Röhl H-J, Schmid-Röhl A (2005) Lower Toarcian (Upper Liassic) Black Shales of the Central European Epicontinental Basin: a sequence stratigraphic case study from the SW German Posidonia Shale. SEPM Soc Sed Geol Spec Publ 82:165-189

Röhl H-J, Schmid-Röhl A, Oschmann W, Frimmel A, Schwark L (2001) Erratum to "The Posidonia Shale (Lower Toarcian) of SWGermany: an oxygen-depleted ecosystem controlled by sea level and palaeoclimate". Palaeogeogr Palaeoclimatol Palaeoecol 169: 273-299

Schieber J, Southard J, Thaisen K (2007) Accretion of mudstone beds from migrating floccule ripples. Science 318:1760-1763

Schmid-Röhl A, Röhl H-J (2003) Overgrowth on ammonite conchsenvironmental implications of the Lower Toarcian Posidonia Shale. Palaeontology 46:339-352

Scholle PA, Arthur MA, Ekdale AA (1983) Pelagic environment. In: Scholle PA, Bebout DG, Moore CH (eds) Carbonate depositional environments. Am Assoc Petrol Geol Mem 33:619-691

Seilacher A (1982) Posidonia Shale (Toarcian, S. Germany)—stagnate basin model revalidated. In: Gallitelli EM (ed) Palaeontology, essential of historical geology. STEM Mucchi, Modena, pp 25-55

Smith CR, Baco AR (2003) Ecology of whale falls at the deep-sea floor. Oceanogr Mar Biol Annu Rev 41:311-354

Suan G, Rulleau L, Mattioli E, Suchéras-Marx B, Rousselle B, Pittet B, Vincent P, Martin JE, Léna A, Spangenberg JE, Föllmi KB (2013) Palaeoenvironmental significance of Toarcian black shales and event deposits from southern Beaujolais, France. Geol 150:728742

Taylor MA (1987) Reinterpretation of ichthyosaurs swimming and buoyancy. Palaeontology 30:531-535 
Taylor MA (2000) Functional significance of bone ballastin in the evolution of buoyancy control strategies by aquatic tetrapods. Hist Biol 14:15-31

Teather RG (1994) Encyclopedia of underwater investigations. Best Publishing Company, Flagstaff

van Loon AJ (2013) Ichthyosaur embryos outside the mother body: not due to carcass explosion but to carcass implosion. Palaeobio Palaeoenv 93:103-109

Vogel S (1994) Life in moving fluids. Princeton University Press, Princeton

Wahl WR (2009) Taphonomy of a nose dive: bone and tooth displacement and mineral accretion in an Ichthyosaur Skull. Paludicola 7: $107-116$

Weiss RF (1970) The solubility of nitrogen, oxygen and argon in water and seawater. Deep-Sea Res 17:721-735

Weiss RF (1974) Carbon dioxide in water and seawater: the solubility of a non-ideal gas. Mar Chem 2:203-215

Wetzel A, Reisdorf AG (2007) Ichnofabrics elucidate the accumulation history of a condensed interval containing a vertically emplaced ichthyosaur skull. SEPM Soc Sed Geol Spec Publ $88: 241-251$

Wetzel A, Uchman A (1998) Biogenic sedimentary structures in mudstones - an overview. In: Schieber J, Zimmerle W, Sethi P (eds) Shales and mudstones, I. Schweizerbart, Stuttgart, pp 351-369

Wetzel A, Weissert H, Schaub M, Voegelin AR (2013) Seawater circulation on an oolite-dominated carbonate system in an epeiric sea (Middle Jurassic, Switzerland). Sedimentology 60: 19-35

Wiesenburg DA, Guinasso NL Jr (1979) Equilibrium solubilities of methane, carbon monoxide, and hydrogen in water and sea water. J Chem Eng Data 24:356-360

Zammit M, Kear BP, Norris RM (2014) Locomotory capabilities in the early Cretaceous ichthyosaur Platypterygius australis based on osteological comparisons with extant marine mammals. Geol Mag 151:87-99

Ziegler PA (1990) Geological Atlas of Western and Central Europe. Shell Internationale Petroleum Maatschappij, The Hague 